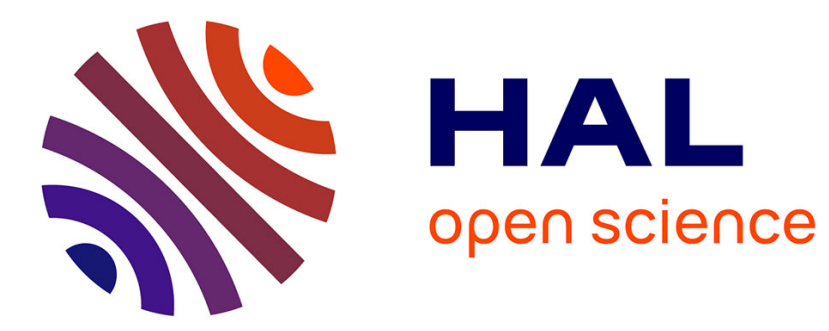

\title{
Pyrolysers configurations effects on scrap waste tires pyrolysis products
}

Rejeb Hiba, Emna Berrich, Mohamed Chahbani

\section{To cite this version:}

Rejeb Hiba, Emna Berrich, Mohamed Chahbani. Pyrolysers configurations effects on scrap waste tires pyrolysis products. 2019 10th International Renewable Energy Congress (IREC), Mar 2019, Sousse, Tunisia. 10.1109/IREC.2019.8754571 . hal-02407544

\section{HAL Id: hal-02407544 \\ https://hal.science/hal-02407544}

Submitted on 12 Dec 2019

HAL is a multi-disciplinary open access archive for the deposit and dissemination of scientific research documents, whether they are published or not. The documents may come from teaching and research institutions in France or abroad, or from public or private research centers.
L'archive ouverte pluridisciplinaire HAL, est destinée au dépôt et à la diffusion de documents scientifiques de niveau recherche, publiés ou non, émanant des établissements d'enseignement et de recherche français ou étrangers, des laboratoires publics ou privés. 


\section{Pyrolysers configurations effects on scrap waste tires pyrolysis products}

\author{
Rejeb hiba \\ Process Engineering \& Industrial Systems Laboratory \\ LR11ES54, \\ Engineering School of Gabes ENIG, University of Gabes, \\ 6072 Gabes, Tunisia, \\ rejebhiba@gmail.com. \\ Emna Berrich \\ LUNAM Université, Université de Nantes, CNRS, GEPEA, \\ UMR6144,
}

\author{
Institut Mines-Telecom, Nantes- France \\ Emna.Berrich@univ-nantes.fr
}

\author{
CHAHBANI Mohamed Hachemi \\ Process Engineering \& Industrial Systems Laboratory \\ LR11ES54, \\ Higher Institute of Applied Sciences and Technology of \\ Gabes (ISSAT), University of Gabes, \\ chahbani.med_hachemi@yahoo.com.
}

\begin{abstract}
This paper presents End of Life Tires (ELT) pyrolysis results in two batch reactors with different configurations. The first setup is constituted of a pyrolyser with $17 \mathrm{~cm}$ of diameter and $17 \mathrm{~cm}$ of cylindrical height. An external electrical heater was used for heating the circumferential walls and the bottom of the pyrolyser. It can reach 400 Watts. The mass used was equals to $100 \mathrm{~g}$. The second setup is bigger than the first one. It consists of a cylindrical fixed-bed reactor made of stainless steel with an internal diameter of $160 \mathrm{~cm}$ and a height of $250 \mathrm{~cm}$. The reactor is placed in an enclosure heated by an electric furnace. The reactor heating power is controllable and may reach 5 kilowatts. It allows only the heating of the pyrolyser circumferential walls. We used $300 \mathrm{~g}$. The heating rate was fixed to $10{ }^{\circ} \mathrm{C} / \mathrm{min}$ and the Nitrogen $\mathrm{N}_{2}$ flow rate to $Q_{\mathrm{N} 2}$ equals to 40 $\mathrm{ml} / \mathrm{min}$. The Thermo-Gravimetric analysis TGA shows that the maximal degradation temperature is approximately equals to 400 ${ }^{\circ} \mathrm{C}$ and the volatile yield (gases and liquid) is $60.35 \mathrm{wt} \%$. It is found that the End of Life Tires pyrolysis produce $30.53 \mathrm{wt} \%$ of Tire Derivative Oil (TDO) using setup 1 and 34.37 wt.\% using setup 2. The tire-derived oils properties i.e. the density, the viscosity and the higher calorific value $\mathrm{HCV}$ are measured and compared to other commercial oils.
\end{abstract}

Keywords - End of Life Tires (ELT), pyrolysis, enrgetic valorization, fuel, and Gas chromatography - mass spectrometry (GC-MS).

\section{Introduction}

Worldwide, the amounts of used polymer products are increasing by the year: most of them are used for automobile tires. According to reports from the largest associations of tire and rubber product manufacturers, the annual global production of tires is some 16.55 million tons, which corresponds to an estimated 17 million tons of used tires each year [1]-[3]. With population growing and economic and social development, tires are becoming a major waste produced by means of transport like motorcars, motorcycles, buses, trucks and bicycles. As tires are non-biodegradable and not always recyclable, measures have to be implemented to reduce their negative impact on the environment. Landfill and incineration, which are the conventional ways to handle End of Life Tires (ELT), are no longer sustainable, as they can lead to environmental damages like soil impregnation, air pollution and water contamination.

Nowadays, thermal cracking, or pyrolysis, is one of the promising methods to treat the End of Life Tires (ELT). Pyrolysis involves heating of polymeric material under atmospheric pressure using inert atmosphere. The process is conducted at temperatures between $250-700^{\circ} \mathrm{C}$ and is useful to break down the ELT into three products, oil, gas and char [4].

The most common rubbers used for tires are : Natural Rubber (NR), Styrene-Butadiene Rubber (SBR) and Butadiene Rubber (BR). Sulfur is used to vulcanizing, steel and carbon black are used as reinforcing agents and aromatic extender oil is used to soften and enhance the workability of rubber. All of these components are $100 \%$ recyclable.

Many researchers have investigated pyrolysis of End of Life Tires (ELT). Aydin and al (2012) [5] used End of Life Tires (ELT) without steel and fabric, in a fixed bed reactor in nitrogen over the temperature range of $400-700{ }^{\circ} \mathrm{C}$. They found that the liquid yield increased from $31 \%$ at $400{ }^{\circ} \mathrm{C}$ to 40 $\%$ at $500^{\circ} \mathrm{C}$. They investigated the influence of nitrogen flow rate on product yield and found only negligible differences in yield.

Kar (2011) [6] investigates the influence of pyrolysis temperature, used $10 \mathrm{~g}$ of End of Life Tires (ELT) batches in a fixed bed, nitrogen purged reactor at $10{ }^{\circ} \mathrm{C} / \mathrm{min}$ heating rate in the range of temperature from 375 to $500{ }^{\circ} \mathrm{C}$. He found that the maximum oil yield of $60.0 \%$ oil was obtained at $425{ }^{\circ} \mathrm{C}$. The oil yield decreased to $54.12 \%$ at the higher temperature of pyrolysis, of $500{ }^{\circ} \mathrm{C}$. When the temperature of pyrolysis was increased from 375 to $500{ }^{\circ} \mathrm{C}$, the gas yield increased from 2.99 to $20.22 \%$ and char yield decreased from 50.67 to 26.41 $\%$. 
Islam and al. (2011) using a fixed bed reactor pyrolysed $750 \mathrm{~g}$ of End of Life Tires (ELT). They also found a high oil yield of $55 \%$ at $475{ }^{\circ} \mathrm{C}$ pyrolysis temperature, a char yield of $36 \%$ and a gas yield of $9 \%$ [7].

Kaminsky and al [8] reported in their paper that the pyrolysis of synthetic and natural rubber in fluidized bed process allowed to obtain high amounts of monomers like isobutene and isoprene.

Alkhatib and al (2015) studied the pyrolysis of End of Life Tires (ELT) in a fixed bed reactor at a low heating rate and reaching $500^{\circ} \mathrm{C}$. They found a high oil yield of $53.49 \%$ when the power is 1500 watt with a corresponding char and gas yield of $38.62 \%$ and $7.89 \%$ respectively. [9]

In this work, End of Life Tires (ELT) were chosen as a raw material with the objective to study the effect of heating reactor mode on the pyrolysis products. ELT pyrolysis was carried out in two different fixed-bed reactors with different heating modes, in order to investigate their effects on the products. Reactors were heated to a final temperature of $600^{\circ} \mathrm{C}$, at a heating rate of $10^{\circ} \mathrm{C} / \mathrm{min}$ and $\mathrm{N}_{2}$ flow rate 40 $\mathrm{ml} / \mathrm{min}$. The physical properties and the chemical compositions of the pyrolytic oil were investigated.

\section{Experimental}

\section{A. Materials and methods}

The raw materials tested in this study are End of Life Tires (ELT) powders from passenger cars that have been brought from a Collection Company in France. Tires powder used did not contain all reinforced materials (wires, fibers). Tires powder dimensions ranged between $1 \times 1 \times 1 \mathrm{~mm}^{3}$ and $2 \times 3 \times$ $1 \mathrm{~mm}^{3}$.

The elemental analysis results in TABLE I show that End of Life Tires is rich in carbon $\mathrm{C}(\approx 81 \%)$ and oxygen $\mathrm{O}(\approx$ $11 \%)$ and has a low Nitrogen $N(0.47 \%)$ content. These results are interesting in the application of ELT in gasification and pyrolysis processes. The $\mathrm{H} / \mathrm{C}$ and $\mathrm{O} / \mathrm{C}$ ratios were 0.134 and 0.084 respectively. Therefore, the empirical formula of ELT is $\mathrm{CH}_{0.134} \mathrm{O}_{0.084} \mathrm{~N}_{0.006} \mathrm{~S}_{0.013}$.

TABLE I. END OF LIFE TIRES (ELT) CHARACTERIZATION.

\begin{tabular}{|c|c|c|c|c|c|c|}
\hline \multicolumn{5}{|c|}{ Elemental Analysis (wt.\%) } & \multirow{2}{*}{ Ash (wt.\%) } & \multirow{2}{*}{ HCV(MJ/kg) } \\
\hline $\boldsymbol{N}$ & $\boldsymbol{C}$ & $\boldsymbol{O}$ & $\boldsymbol{H}$ & $\boldsymbol{S}$ & & \\
\hline 0.47 & 80.82 & 6.79 & 10.81 & 1.11 & 11 & 32.57 \\
\hline
\end{tabular}

\section{B. Thermo-gravimetric analysis $T G$}

Pyrolysis tests were carried out using thermo gravimetric analysis coupled with differential scanning calorimetric (SETARAM SETSYS Evolution-TG-DSC apparatus), equipped with a graphite furnace and a balance with a maximum capacity of $35 \mathrm{~g}$ and a resolution of $0.002 \mu \mathrm{g}$. An argon flow is passed through the head of the thermo balance to prevent corrosion of the microbalance from the produced and introduced gases. The sample temperature was measured by a thermocouple placed in the reaction atmosphere, at $15 \mathrm{~mm}$ below the sample pan. About $20 \mathrm{mg}$ of sample was pyrolysed using a cylindrical platinum crucible of $130 \mu \mathrm{l}$ of volume and a very low height to diameter ratio $(\approx 0.25)$. A flow of 100 $\mathrm{ml} / \mathrm{min}$ of pure nitrogen was introduced to ensure an inert atmosphere during the pyrolysis of the sample which was heated from room temperature to $600{ }^{\circ} \mathrm{C}$ under atmospheric pressure and at a heating rate of $10^{\circ} \mathrm{C} / \mathrm{min}$.

\section{Pyrolysis setups with and without heating at the pyrolyser bottom}

Two reactors were used in pyrolysis experiments. The first pyrolysis setup is shown in Fig. 1 .It is constituted of : Nitrogen gas tank, Acquisition controller (2), Labview software (1), heating up resistance (4) which allows a heating at the bottom and the circonferential walls of the pyrolyser, reactor made of stainless steel (6), row material (5), pressure sensor (8), condenser (9), fuel receiving flask (12), non-condensable gases outlet (16). The reactor has as dimensions: $17 \mathrm{~cm}$ diameter and $17 \mathrm{~cm}$ height cylindrical. Glass Wool was used for the reactor heat insulation. An external electrical heater was used for heating. It can reach 400 Watts. The wall temperature is measured by a thermocouple ( $\mathrm{T}_{0}$, and controlled by a PID controller.

The second pyrolysis setup is shown in Fig. 2. It consists of a cylindrical fixed-bed reactor made of stainless steel (internal diameter of $160 \mathrm{~cm}$ and a height of $250 \mathrm{~cm}$ (Almost $10 *$ Diameter of the setup $1,250 / 17=14.7 *$ the height of the setup 1). The reactor is placed in an enclosure heated by an electric furnace and which can reach a maximum temperature of 1000 ${ }^{\circ} \mathrm{C}$, the reactor heating power is controllable and may reach 5 kilowatts. It allows only the heating of the pyrolyser circonferential walls. The wall temperature is measured by a thermocouple $\left(\mathrm{T}_{\text {reg }}\right)$, and controlled by a PID controller.

For both of them, the reactors were purged using a high Nitrogen flow for 4-6 min before the beginning of each experiment to make sure that the system is filled with inert gas (pyrolysis conditions). This was verified by micro-Gases Chromatography analysis. The oxygen percentage was less than $1 \%$ before heating. We used $100 \mathrm{~g}$ in the seutp 1 and 300 $\mathrm{g}$ in setup 2 as it is bigger than setup 1 . The produced volatile gases are evaporated out of the reactor into a water-cooled counter-current condenser. The condensable liquid products produced during the pyrolysis are condensed in a heat exchanger cooled by water at a temperature of $10{ }^{\circ} \mathrm{C}$ and collected in a flask, the non condensable gases are discharged to atmosphere. The collected liquid in the receiving flask (12) is characterized by viscosity, density and higher Calorific Values (HCV). 


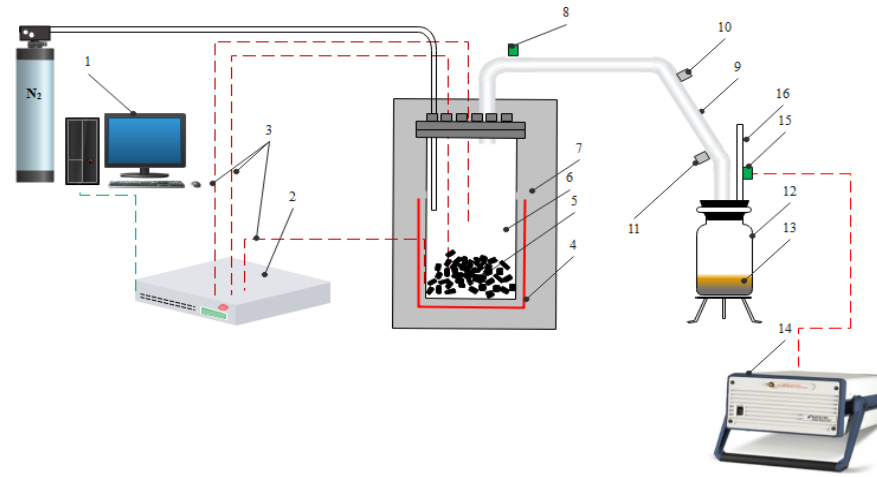

Fig. 1. First pyrolysis setup with a heating system at the bottom and the circonferential walls of the pyrolyser.

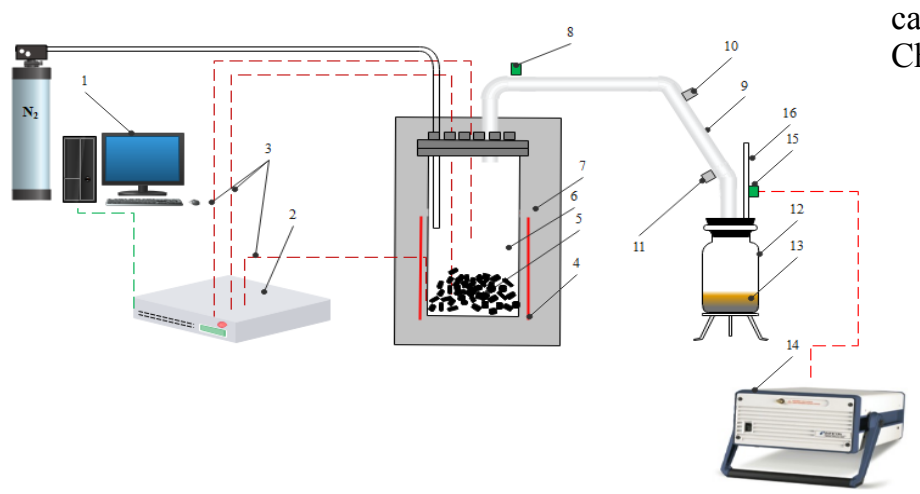

Fig. 2. Second pyrolysis setup with a heating system only on the circonferential walls of the pyrolyser.

\section{Gas chromatography-mass spectroscopy (GC-MS)}

In order to quantify the dominant chemical compounds of the pyrolytic oils, samples were analyzed using GC-MS spectrometer coupled with flame ionization detector FID. An agilent SLB-5MS column $(30 \mathrm{mx} 0.250 \mathrm{~mm} ; 0.25 \mu \mathrm{m}$ film thickness) was used with a helium flow rate $1 \mathrm{ml} / \mathrm{min}$. The temperature program began with a hold at $70^{\circ} \mathrm{C}$ for $1 \mathrm{~min}$ followed by an increase at $12^{\circ} \mathrm{C} / \mathrm{min}$ to $180^{\circ} \mathrm{C}$, then $12^{\circ} \mathrm{C} / \mathrm{min}$ to $330^{\circ} \mathrm{C}$, which was held for $1 \mathrm{~min}$. the temperature of FID was fixed at $275^{\circ} \mathrm{C}$. Injections of $0.5 \mu \mathrm{l}$ of oil samples were realized with a split ratio of 10:1:5 mg of products were dissolved in $1 \mathrm{ml}$ of heptane. Identification of chromatographic peaks was established from MS data, which was matched to the NIST spectral library.

\section{RESULTS AND DISCUSSION}

\section{A. TG and DTG analysis of ELT}

TG analysis is a thermal analysis technique that measures the material weight evolution as a function of temperature and time, in a controlled environment. TG was applied to study End of Life Tires (ELT) thermal degradation in various temperature ranges.

From the TG-DTG curves shown in Fig. 3, the End of Life Tires (ELT) thermal degradation evolution represents two peaks indicating that there are two degradation steps where the conversion takes place. The degradation starts at $200{ }^{\circ} \mathrm{C}$.
Then, with the temperature rise, the degradation rate increases until reaching its maximum at $420{ }^{\circ} \mathrm{C}$. The ELT thermal degradation was completed at $500{ }^{\circ} \mathrm{C}$ for the heating rate 10 ${ }^{\circ} \mathrm{C} / \mathrm{min}$ and a Nitrogen flow rate of $40 \mathrm{ml} / \mathrm{min} \mathrm{T}_{\max }$ at which the conversion is maximum is about $420{ }^{\circ} \mathrm{C}$ as shown in Fig. 3 .The volatile yield materials are around $60 \%$. The results obtained by J. H. Chen and al [4] who used a Nitrogen flow rate fixed at $50 \mathrm{ml} / \mathrm{min}$, a heat rates $\beta=5,10,20$ and 30 $\mathrm{K} / \mathrm{min}$, show that in this condition, the initial temperature varied from $209^{\circ} \mathrm{C}$ to $248{ }^{\circ} \mathrm{C}$ for the passenger car tire of and from $185^{\circ} \mathrm{C}$ to $238{ }^{\circ} \mathrm{C}$ for truck tire. The final temperature varied from 501 to $548{ }^{\circ} \mathrm{C}$ for the tire of passenger car and from 493 to $553{ }^{\circ} \mathrm{C}$ for truck tire. The $\mathrm{T}$ max temperature is in the range $\left[396-425^{\circ} \mathrm{C}\right]$ and $\left[392-430^{\circ} \mathrm{C}\right]$ respectively. In this work we used End of Life Tires (ELT) from passenger cars. The thermal degradation ranges obtained agree with J. H. Chen and al 's work [4].

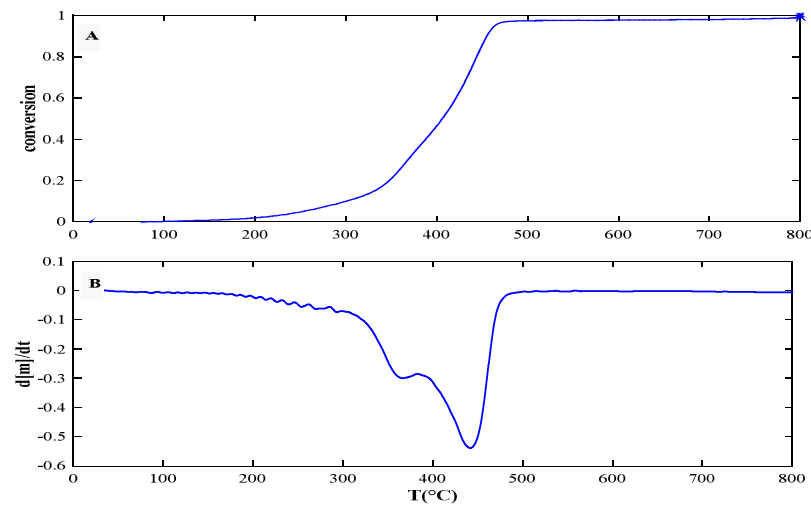

Fig. 3. TG and DTG curves of End of Life Tires (ELT) a: TG, b:DTG.

\section{B. ELT pyrolysis products characterics \\ 1) ELT pyrolysis products yields}

The ELT pyrolysis products were classified into three groups: gas, liquid (Tires Derived Oil TDO) and solid.

TABLE II shows the yields pyrolysis products distribution. With setup 1, the pyrolysis products' yields are respectively 30.81 wt. $\%$ for the liquid, 17.85 wt.\% for the gas and 51.60 wt. $\%$ for the solid for the experiments' conditions used. While when using setup 2, the liquid yield increases to 34.37 wt.\%, the solid yield passed to $54.59 \mathrm{wt} . \%$, and the gas yield decreases to 11.04 wt.\%. With comparison to the Aydin et Ilkiliç work [5] who used a Nitrogen flow rate varied from 150 $\mathrm{ml} / \mathrm{min}$ to $350 \mathrm{ml} / \mathrm{min}$ and a heating rate of $12{ }^{\circ} \mathrm{C} / \mathrm{min}$, the authors found that at $500{ }^{\circ} \mathrm{C}$, the liquid yield decreases from $39.85 \%$ to $38.8 \%$ while increasing the flow rate from 150 to $350 \mathrm{ml} / \mathrm{min}$. While, for the same previous conditions, the gas yield increases from $12.03 \mathrm{wt} \%$ to $14.9 \mathrm{wt} \%$. Thus, our liquid and gas yields obtained for a Nitrogen flow rate of $40 \mathrm{ml} / \mathrm{min}$ and a heating rate of $10{ }^{\circ} \mathrm{C} / \mathrm{min}$ without maintaining the maximum temperature during supplementary heating seems to be good energetic experiments' conditions as they allow to reduce the nitrogen flow rate used and the energetic costs related to heating. Comparing to $\mathrm{H}$. Aydin and C. Ilkiliç's work[5], they found that the yields were $40.26 \mathrm{wt} \%, 47.88$ 
wt.\% and $11.86 \mathrm{wt} . \%$ respectively for the liquid, the solid and the gas for a heating rate of $12{ }^{\circ} \mathrm{C} / \mathrm{min}$ until $500{ }^{\circ} \mathrm{C}$ and 200 $\mathrm{ml} / \mathrm{min}$ of $\mathrm{N}_{2}$ flow rate. However, they have used small tires pieces after cutting them to slices and removing steel wires and fabric fibers. Our gas and solid yields obtained are higher than those of H. Aydin and C. Ilkiliç's work [5] when using setup 1. However, our liquid yield for the two reactors was less than theirs. The yields values found by S. Boxiong et al [10] were 32.1 wt. $\%, 35$ wt. $\%$ and $25 \mathrm{wt} . \%$ respectively for the liquid, the solid and the gas for a heating rate of $10{ }^{\circ} \mathrm{C} / \mathrm{min}$ until $500{ }^{\circ} \mathrm{C}$. They used a tire material shredded and crumbed without steel. Their liquid yield is equals to our liquid yield when using setup 1 , for a heating rate of $10{ }^{\circ} \mathrm{C} / \mathrm{min}$ until $500{ }^{\circ} \mathrm{C}$ and is lesser than our liquid yield when using setup 2. Tire pyrolysis is strongly dependent on type of inter- and intra-molecular bonding that exists among the polymers that makes up the tires and tire composition [11] this can be a reason to the difference between this result and other previous results.

TABLE II. PRODUCTS YIELDS OBTAINED FROM END OF LIFE TIRES (ELT) PYROLYSIS BY SETUP 1 AND 2.

\begin{tabular}{|c|c|c|}
\cline { 2 - 3 } \multicolumn{1}{c|}{} & Setup 1 & Setup 2 \\
\hline \multicolumn{3}{c|}{ Product yield (\%) } \\
\hline liquid & 30.81 & 34.37 \\
\hline gas & 17.85 & 11.04 \\
\hline solid & 51.60 & 54.59 \\
\hline
\end{tabular}

\section{2) GC-MS of the TDO}

The identification of liquid compounds was carried out using gas chromatography-mass spectrometry GC-MS analysis. The peaks with $\mathrm{P} 80 \%$ mach quality were considered valid, that their provisional assignments were consistent with published GM / MS data of similar products [12-14].

The derived oil (TDO) Chromatograms obtained from End of Life Tires (ELT) using setup 1 is shown in Fig. 4 and TABLE III. It is obvious that TDO products consist mainly of a variety of aromatic compounds with few aliphatic compounds.

TABLE III shows the TDO compounds, its retention times and its weight percentages. It can be seen that TDO is a very complex mixture of $\mathrm{C} 5-\mathrm{C} 16$ organic compounds with high concentration of unsaturated compounds. The total concentrations of aromatic and aliphatic compounds were 16.51 and 15.73 wt. $\%$, respectively.

The Chromatograms of TDO obtained from setup 2 is shown in Fig. 5. Compound name, its formula, its retention time and it weight percentage are shown in TABLE IV.

It is clear from Fig. 4 that the main products obtained in setup 1 are the D-limonene, benzene derivatives and very small amounts of other aliphatic/aromatic compounds. While TDO obtained from setup 2, contains a very wide and complicated range of aliphatic/aromatic compounds.
In Fig. 4 and Fig. 5, D-limonene $\left(\mathrm{C}_{10} \mathrm{H}_{16}\right)$ is the dominant compound with more aliphatic compounds and single ring aromatic. D-limonene is a favorable product because of its wide important uses as a feedstock in many industries [15], [16].Production all over the pyrolysis process of D-limonene indicates that dehydrogenation /cyclisation/ aromatization reactions always take place during the pyrolysis as D-limonene is produced [17].

In pyrolytic oil obtained using setup 2 , the most important components are aromatics (1-Methyl-naphthalene, $1 \mathrm{H}-$ Indene....), followed by alkanes (Limonene) and nonhydrocarbons (Benzothiazole, 2-Methoxy-4-(1-propenyl)phenol...) ) which confirmed by previous literatures [17].

Benzothiazole, a nitrogen- and sulphur-containing compound $\left(\mathrm{C}_{7} \mathrm{H}_{5} \mathrm{NS}\right)$, was also determined at a concentration of $1.27 \mathrm{wt} \%$. The presence of this compound may be explained by thermal degradation of the accelerators used for the vulcanization of rubber which are frequently sulphur and/or nitrogen based organic compounds, such as 2-mercaptobenzothiazole and benzothiazole, disulphide[17].

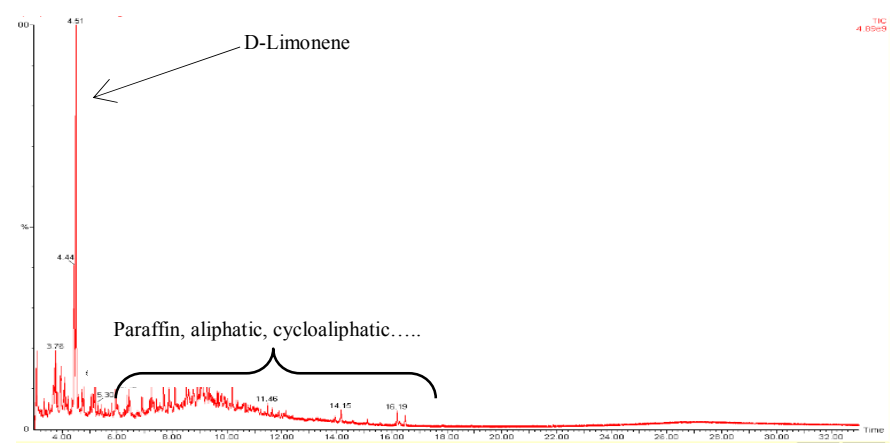

Fig. 4. GC/MS of TDO setup 1.

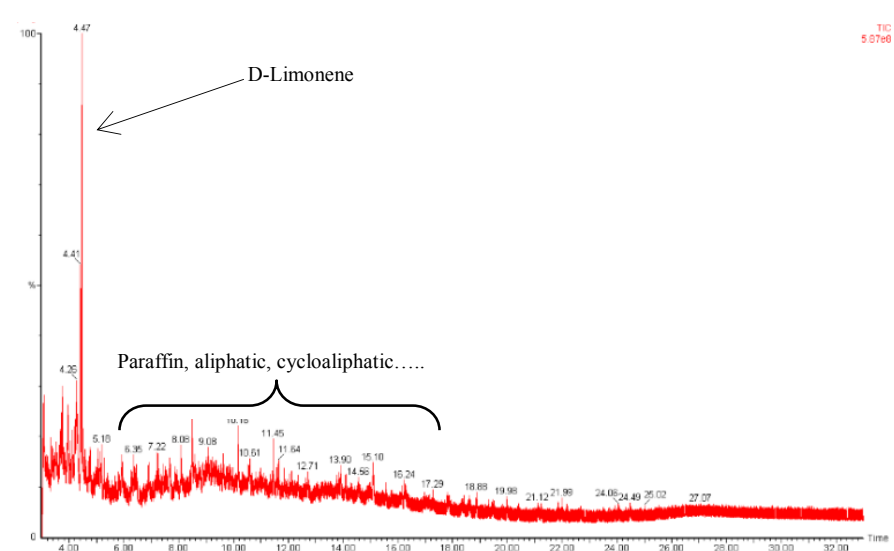

Fig. 5. GC/MS of TDO setup 2.

TABLE III. RETENTION TIMES (RT) OF CHEMICAL COMPOUNDS IN THE TDO FOR SETEP 1 .

\begin{tabular}{|c|c|c|c|}
\hline RT & compound & Formula & \% \\
\hline 3.071 & p-Xylene & $\mathrm{C}_{8} \mathrm{H}_{10}$ & 1.59 \\
\hline 3.766 & Benzene, 1-ethyl-3-methyl- & $\mathrm{C}_{9} \mathrm{H}_{12}$ & 1.566 \\
\hline 3.962 & $\begin{array}{c}\text { 2H-Indeno[1,2-b]oxirene, octahydro-, } \\
\text { (1aà,1bá,5aà,6aà)- }\end{array}$ & $\mathrm{C}_{9} \mathrm{H}_{14} \mathrm{O}$ & 2.82 \\
\hline
\end{tabular}




\begin{tabular}{|c|c|c|c|}
\hline 4.446 & Benzene, 1-methyl-4-(1-methylethyl)- & $\mathrm{C}_{10} \mathrm{H}_{14}$ & 3.65 \\
\hline 4.528 & D-Limonene & $\mathrm{C}_{10} \mathrm{H}_{16}$ & 11.84 \\
\hline 4.789 & 1H-Cycloprop[c]inden-7-ol, octahydro- & $\mathrm{C}_{10} \mathrm{H}_{16} \mathrm{O}$ & 1.359 \\
\hline 5.195 & 1-Phenyl-1-butene & $\mathrm{C}_{10} \mathrm{H}_{12}$ & 1.48 \\
\hline 5.398 & $\begin{array}{l}\text { Benzene, 1-(1,5-dimethylhexyl)-4- } \\
\text { methyl- }\end{array}$ & $\mathrm{C}_{15} \mathrm{H}_{24}$ & 1.19 \\
\hline 5.929 & $\begin{array}{l}\text { Hydrocinnamic acid, o-[(1,2,3,4- } \\
\text { tetrahydro-2-naphthyl)methyl]- }\end{array}$ & $\mathrm{C}_{20} \mathrm{H}_{22} \mathrm{O}_{2}$ & 1.63 \\
\hline 6.36 & 1H-Indene, 2,3-dihydro-1,2-dimethyl- & $\mathrm{C}_{11} \mathrm{H}_{14}$ & 0.82 \\
\hline 6.463 & Pentamethylbenzenesulphonamide & $\mathrm{C}_{11} \mathrm{H}_{17} \mathrm{NO}_{2} \mathrm{~S}$ & 1.11 \\
\hline 6.901 & Benzothiazole & $\mathrm{C}_{7} \mathrm{H}_{5} \mathrm{NS}$ & 1.27 \\
\hline 7.232 & $\begin{array}{l}\text { 7-(1-Hydroxy-cyclohex-2-enyl)-2,2- } \\
\text { dimethyl-hept-5-en-3-one }\end{array}$ & $\mathrm{C}_{15} \mathrm{H}_{24} \mathrm{O}_{2}$ & 0.76 \\
\hline 7.674 & $\begin{array}{l}\text { Hydrocinnamic acid, o-[(1,2,3,4- } \\
\text { tetrahydro-2-naphthyl)methyl]- }\end{array}$ & $\mathrm{C}_{20} \mathrm{H}_{22} \mathrm{O}_{2}$ & 1.86 \\
\hline 8.087 & $\begin{array}{l}\text { 7-(1-Hydroxy-cyclohex-2-enyl)-2,2- } \\
\text { dimethyl-hept-5-en-3-one }\end{array}$ & $\mathrm{C}_{15} \mathrm{H}_{24} \mathrm{O}_{2}$ & 1.14 \\
\hline 8.493 & $\begin{array}{l}\text { Benzoic alcohol, 2,6-difluoro-5- } \\
\text { methyl- }\end{array}$ & $\mathrm{C}_{8} \mathrm{H}_{8} \mathrm{~F}_{2} \mathrm{O}$ & 0.81 \\
\hline 10.15 & 1H-Indole, 4-(3-methyl-2-butenyl)- & $\mathrm{C}_{13} \mathrm{H}_{15} \mathrm{~N}$ & 0.32 \\
\hline 10.577 & 2,5-Octadecadiynoic acid, methyl ester & $\mathrm{C}_{19} \mathrm{H}_{30} \mathrm{O}_{2}$ & 0.22 \\
\hline 11.432 & Limonen-6-ol, pivalate & $\mathrm{C}_{15} \mathrm{H}_{24} \mathrm{O}_{2}$ & 0.15 \\
\hline 12.091 & 5,8,11,14-Eicosatetraynoic acid & $\mathrm{C}_{20} \mathrm{H}_{24} \mathrm{O}_{2}$ & 0.09 \\
\hline 13.89 & 1-Heptatriacotanol & $\mathrm{C}_{37} \mathrm{H}_{76} \mathrm{O}$ & 0.08 \\
\hline
\end{tabular}

TABLE IV. RT OF CHEMICAL COMPOUNDS IN THE TDO FOR SETEP

\begin{tabular}{|c|c|c|c|}
\hline RT & compound & Formula & $\%$ \\
\hline 3.064 & p-Xylene & $\mathrm{C}_{8} \mathrm{H}_{10}$ & 0.94 \\
\hline 3.349 & $\begin{array}{c}\text { Tricyclo[3.2.2.0]nonane-2-carboxylic } \\
\text { acid }\end{array}$ & $\mathrm{C}_{10} \mathrm{H}_{14} \mathrm{O}_{2}$ & 0.54 \\
\hline 3.51 & $\begin{array}{l}\text { Cyclohexanol, 2-methyl-5-(1- } \\
\text { methylethenyl)-, (1à,2á,5à)- }\end{array}$ & $\mathrm{C}_{10} \mathrm{H}_{18} \mathrm{O}$ & 0.54 \\
\hline 3.752 & Benzene, 1,2,4-trimethyl- & $\mathrm{C}_{9} \mathrm{H}_{12}$ & 0.56 \\
\hline 3.955 & $\begin{array}{c}\text { 3-Methylene-bicyclo[3.2.1]oct-6-en-8- } \\
\text { ol }\end{array}$ & $\mathrm{C}_{9} \mathrm{H}_{12} \mathrm{O}$ & 1.15 \\
\hline 4.421 & Benzene, 1-methyl-4-(1-methylethyl)- & $\mathrm{C}_{10} \mathrm{H}_{14}$ & 1.66 \\
\hline 4.489 & D-Limonene & $\mathrm{C}_{10} \mathrm{H}_{16}$ & 3.25 \\
\hline 4.774 & 1H-Cycloprop[c]inden-7-ol, octahydro- & $\mathrm{C}_{10} \mathrm{H}_{16} \mathrm{O}$ & 0.63 \\
\hline 5.12 & $\begin{array}{l}\text { Benzene, 1-methyl-4-(1- } \\
\text { methylethenyl)- }\end{array}$ & $\mathrm{C}_{10} \mathrm{H}_{12}$ & 0.51 \\
\hline 5.398 & $\begin{array}{l}\text { Benzene, 1-(1,5-dimethylhexyl)-4- } \\
\text { methyl- }\end{array}$ & $\mathrm{C}_{15} \mathrm{H}_{24}$ & 0.55 \\
\hline 5.932 & 4-Methyl-á-methyl-á-nitrostyrene & $\mathrm{C}_{10} \mathrm{H}_{11} \mathrm{NO}_{2}$ & 0.88 \\
\hline 6.36 & $\begin{array}{l}\text { Hydrocinnamic acid, o-[(1,2,3,4- } \\
\text { tetrahydro-2-naphthyl)methyl]- }\end{array}$ & $\mathrm{C}_{20} \mathrm{H}_{22} \mathrm{O}_{2}$ & 0.35 \\
\hline 6.467 & Benzene, (1,1-dimethyl-2-propenyl)- & $\mathrm{C}_{11} \mathrm{H1}_{4}$ & 0.53 \\
\hline 6.894 & Benzothiazole & $\mathrm{C}_{7} \mathrm{H}_{5} \mathrm{NS}$ & 0.82 \\
\hline 7.233 & N-Methyltomatidine & $\mathrm{C}_{15} \mathrm{H}_{24} \mathrm{O}_{2}$ & 0.49 \\
\hline 7.678 & $\begin{array}{l}\text { Hydrocinnamic acid, o-[(1,2,3,4- } \\
\text { tetrahydro-2-naphthyl)methyl]- }\end{array}$ & $\mathrm{C}_{20} \mathrm{H}_{22} \mathrm{O}_{2}$ & 0.64 \\
\hline 8.088 & $\begin{array}{l}\text { 7-(1-Hydroxy-cyclohex-2-enyl)-2,2- } \\
\text { dimethyl-hept-5-en-3-one }\end{array}$ & $\mathrm{C}_{15} \mathrm{H}_{24} \mathrm{O}_{2}$ & 1.15 \\
\hline 8.498 & $\begin{array}{l}\text { Oct-3-ene-1,5-diyne, 3-t-butyl-7,7- } \\
\text { dimethyl- }\end{array}$ & $\mathrm{C}_{14} \mathrm{H}_{20}$ & 0.71 \\
\hline 9.078 & Naphthalene, 1,3-dimethyl- & $\mathrm{C}_{12} \mathrm{H}_{12}$ & 0.45 \\
\hline 10.173 & Naphthalene, 2,3,6-trimethyl- & $\mathrm{C}_{13} \mathrm{H}_{14}$ & 1.48 \\
\hline 13.914 & $\begin{array}{l}\text { Morphinan-4,5-epoxy-3,6-di-ol, 6-[7- } \\
\text { nitrobenzofurazan-4-yl]amino- }\end{array}$ & $\mathrm{C}_{26} \mathrm{H}_{27} \mathrm{~N}_{5} \mathrm{O}_{6}$ & 0.86 \\
\hline 15.108 & 1-Heptatriacotanol & $\mathrm{C}_{37} \mathrm{H}_{76} \mathrm{O}$ & 1.29 \\
\hline
\end{tabular}

\section{3) Char characterization}

In order to characterize the remaining solid of pyrolysis, some analyses were done for the coal such as HCV and EA. The elemental analyzes were carried out on the pyrolytic products including the carbonaceous residue from each pyrolysis experiments. The results of these analyses are summarized in the TABLE $V$. The results show that the composition of the char issued from setup 1 had a higher carbon (80.5 wt.\%) and sulfur (2.1 wt.\%) weight percentages. While using setup 2, the chars contains 79 wt.\% of carbon and 2.14 wt.\% of sulfur. According to Williams [18] chars have high sulphur contents reported to be between $1.9 \mathrm{wt} . \%$ and $2.7 \mathrm{wt} . \%$ and high carbon contents of up to $80.3 \mathrm{wt} . \%$ and $90 \mathrm{wt} . \%$. Thus our results agree with Williams [18] ones. The results revealed that the ash content are equal to $14 \mathrm{wt} . \%$ for both setups. This high values of ash can be related to the additive mostly zinc, added in the formulation of the tire and dirt material found on End of Life Tires (ELT). This values are in conformity with [18] results who found percentages 8.27 and $15.33 \mathrm{wt} . \%$.

Considering that the original tire sample contained 1.11 wt.\% of sulphur and that the solid yield was about 51 wt.\%, thus about $60 \%$ of the tire sulphur was left in the solid residue and the rest remained in the liquid fraction mainly as benzothiazole as illustrated on TABLE III and TABLE IV. Owing to the high $\mathrm{C}$ content of the char (80 wt.\%), its HCV $(30 \mathrm{MJ} / \mathrm{kg})$, is greater than coals one.

The char (solid) residue from End of Life Tires (ELT) pyrolysis may have potential applications such us filler in road bitumen, active carbon (using chemical or physical activation), carbon black for manufacture (as raw material to rubber) or solid combustion [19].

TABLE V. CHAR PROPRIETIES

\begin{tabular}{|c|c|c|c|c|c|c|c|}
\cline { 2 - 7 } \multicolumn{1}{c|}{} & \multicolumn{5}{c|}{ Elemental Analysis (wt.\%) } & \multirow{2}{*}{$\begin{array}{c}\text { Ash } \\
\text { (wt.\%) }\end{array}$} & HCV(MJ/kg) \\
\cline { 2 - 7 } & $\boldsymbol{N}$ & $\boldsymbol{C}$ & $\boldsymbol{O}$ & $\boldsymbol{H}$ & $\boldsymbol{S}$ & 14 & 30 \\
\hline Setup 1 & 0.18 & 80.5 & 0.75 & 1.48 & 2.1 & 14 & 31.2 \\
\hline Setup 2 & 0.12 & 79.4 & 0.84 & 1.44 & 2.14 & 14 & \\
\hline
\end{tabular}

4) Estimation of diesel fraction

In order to characterize the obtained oils from ELT pyrolysis in terms of fuel properties, pyrolytic oils were compared with diesel fuel (TABLE VI).

The HCVs of both TDO products are similar but lower than diesel HCV. However, the viscosities and densities are different. Compared to R. Alkhatib and al [9] results's who used waste shredded tires as raw material without any catalyst, they found that the liquid $\mathrm{HCV}$ values were respectively equal to $43.43,43.47$ and $43.4735 \mathrm{MJ} / \mathrm{kg}$ for heating powers respectively of 750,1500 and $3000 \mathrm{~W}$.

The Low Calorific Value LCVs of both TDO products are similar equal to 40.712 and $40.148 \mathrm{MJ} / \mathrm{kg}$ respectively for setup 1 and 2 but lower than diesel LCV (43.1 MJ $/ \mathrm{kg})$.

Li et al (2004) used a pilot scale rotary kiln reactor to pyrolysis tires over a range of temperatures from 450 to $650{ }^{\circ} \mathrm{C}$ [20] The tires derived oil (TDO) produced during pyrolysis of used tires with setup 1 is lighter than the tires derived oil (TDO) obtained with setup 2 and close to diesel ones. The density values of TDO with setup $1(0.87 \mathrm{~g} / \mathrm{ml})$ are close to the density value obtained by M. Ambrosewicz-walacik and M. 
Walacik, [21] . The tires derived oil (TDO) viscosities for setup 1, setup 2 and diesel are equal to 1.51, 2.3 and 2.14 (mPa.s) at $40{ }^{\circ} \mathrm{C}$ respectively. This can be explained by the effect of the reactor configuration and the weight of the raw material. It is clear that each pyrolytic liquid has higher density and lower $\mathrm{HCV}$ values than diesel ones. Comparing both setups, setup 2 has a higher potential of oil production than setup 1.The oil obtained from setup 2 has a higher density compared to diesel.

\section{TABLE VI. TDO AND DIESEL PROPERTIES, *LCV(LOW CALORIFIC} VALUE).

\begin{tabular}{|c|c|c|c|}
\hline Properties/fuel & $\begin{array}{c}\text { TDO of } \\
\text { Setup 1 }\end{array}$ & $\begin{array}{c}\text { TDO of } \\
\text { Setup 2 }\end{array}$ & diesel \\
\hline $\begin{array}{c}\text { Viscosity at } 40^{\circ} \mathrm{C} \\
\left(\mathrm{mPa} . \mathrm{s}^{-1}\right)\end{array}$ & 1.51 & 2.3 & 2.14 \\
\hline $\mathrm{HCV}(\mathrm{MJ} / \mathrm{Kg})$ & 43.213 & 42.649 & 45.95 \\
\hline LCV $(\mathrm{MJ} / \mathrm{kg})$ & 40.712 & 40.148 & 43.1 \\
\hline $\begin{array}{c}\text { Flash point } \\
\left({ }^{\circ} \mathrm{C}\right)\end{array}$ & $<30$ & $<30$ & $>60$ \\
\hline $\begin{array}{c}\text { Density } \\
(\mathrm{g} / \mathrm{ml})\end{array}$ & 0.87 & 0.92 & 0.826 \\
\hline
\end{tabular}

\section{Conclusion}

Pyrolysis of ELT to produce diesel-like fuels has been studied using two different setups. Tires powder used did not contain all reinforced materials (wires, fibers). Tires powder dimensions ranged between $1 \times 1 \times 1 \mathrm{~mm}^{3}$ and $2 \times 3 \times 1 \mathrm{~mm}^{3}$.

The elementary analysis results confirmed that the $\mathrm{H} / \mathrm{C}$ and $\mathrm{O} / \mathrm{C}$ ratios were 0.134 and 0.084 respectively. Therefore, the empirical formula of ELT is $\mathrm{CH}_{0.134} \mathrm{O}_{0.084} \mathrm{~N}_{0.006} \mathrm{~S}_{0.013}$.

Comparing both setups, setup 2 has a higher potential of oil production than setup 1. Indeed, Pyrolysis in Setup 1 gave a liquid product yield of $30.81 \mathrm{wt} . \%$. Contrariwise, setup 2 gave a liquid yield of $34.37 \%$. GC studies show that both liquid fuel products consist of aromatics (1-Methyl-naphthalene, 1HIndene...), followed by alkanes (Limonene) and nonhydrocarbons (Benzothiazole, 2-Methoxy-4-(1-propenyl)phenol...) ). D-limonene is the dominant compound with more aliphatic compounds for both setups.

Using setup 1, the HCV and the viscosities were $43.21 \mathrm{MJ} / \mathrm{kg}$ and $1.51 \mathrm{mPas}$ respectively. While, when using setup 2, the $\mathrm{HCV}$ and the viscosities are $42.649 \mathrm{MJ} / \mathrm{kg}$ and $2.3 \mathrm{mPas}$. In order to characterize the obtained TDO from ELT pyrolysis in terms of fuel properties, pyrolytic oils were compared to diesel proprieties.

\section{References}

[1] JATMA, "The Japan Automobile Tyre Manufacturers Association NC (Japan),” Tyre Ind. Japan 2018, 2018.

[2] M. Sienkiewicz, J. Kucinska-Lipka, H. Janik, and A. Balas, "Progress in used tyres management in the European Union: A review," Waste Manag., vol. 32, no. 10, pp. 1742-1751, 2012.
ETRMA, "European Tyre \& Rubber Industry Statistics 2017," The ETRMA Statistics Report. 2017.

[4] J. H. Chen, K. S. Chen, and L. Y. Tong, "On the pyrolysis kinetics of scrap automotive tires," vol. 84, pp. 43-55, 2001.

[5] H. Aydin and C. Ilkiliç, "Optimization of fuel production from waste vehicle tires by pyrolysis and resembling to diesel fuel by various desulfurization methods," Fuel, vol. 102, pp. 605-612, 2012.

[6] Y. Kar, "Catalytic pyrolysis of car tire waste using expanded perlite," Waste Manag., vol. 31, no. 8, pp. 1772-1782, 2011.

[7] M. A. K. and M. R. I. S. M. Rofiqul Islam, M. U. Hossain Joardder, "Solid Waste Management in the Developing Countries," in Valorization of solid tire wastes available in bangladesh by thermal treatment, 2011, no. February, pp. 13-15.

[8] W. Kaminsky, C. Mennerich, and Z. Zhang, "Feedstock recycling of synthetic and natural rubber by pyrolysis in a fluidized bed," $J$. Anal. Appl. Pyrolysis, vol. 85, no. 1-2, pp. 334-337, 2009.

R. Alkhatib, K. Loubar, S. Awad, E. Mounif, and M. Tazerout, "Effect of heating power on the scrap tires pyrolysis derived oil," $J$. Anal. Appl. Pyrolysis, vol. 116, pp. 10-17, 2015.

[10] S. Boxiong, W. Chunfei, G. Binbin, W. Rui, and Liangcai, "Pyrolysis of waste tyres with zeolite USY and ZSM-5 catalysts," Appl. Catal. B Environ., vol. 73, no. 1-2, pp. 150-157, 2007.

[11] A. Quek and R. Balasubramanian, "Mathematical modeling of rubber tire pyrolysis," J. Anal. Appl. Pyrolysis, vol. 95, pp. 1-13, 2012.

[12] M. F. Laresgoiti, B. M. Caballero, I. De Marco, A. Torres, M. A. Cabrero, and M. J. Chomón, "Characterization of the liquid products obtained in tyre pyrolysis," J. Anal. Appl. Pyrolysis, vol. 71, pp. 917-934, 2004.

[13] S. Boxiong, W. Chunfei, L. Cai, G. Binbin, and W. Rui, "Pyrolysis of waste tyres: The influence of USY catalyst / tyre ratio on products," J. Anal. Appl. Pyrolysis, vol. 78, pp. 243-249, 2007.

[14] S. Ucar, S. Karagoz, A. R. Ozkan, and J. Yanik, "Evaluation of two different scrap tires as hydrocarbon source by pyrolysis," Fuel, vol. 84, pp. 1884-1892, 2005.

[15] H. Pakdel, D. Magdalena, and C. Roy, "Production of dl -limonene by vacuum pyrolysis of used tires," vol. 57, pp. 91-107, 2001.

[16] J. D. Martínez, N. Puy, R. Murillo, T. García, M. V. Navarro, and A. M. Mastral, "Waste tyre pyrolysis - A review," Renew. Sustain. Energy Rev., vol. 23, pp. 179-213, 2013.

[17] X. Dai, "Pyrolysis of waste tires in a circulating fluidized-bed reactor," vol. 26, pp. 385-399, 2001.

[18] P. T. Williams, "Pyrolysis of waste tyres: A review," Waste Manag., vol. 33, no. 8, pp. 1714-1728, 2013.

[19] S. Frigo, M. Seggiani, M. Puccini, and S. Vitolo, "Liquid fuel production from waste tyre pyrolysis and its utilisation in a Diesel engine," FUEL, vol. 116, pp. 399-408, 2014.

[20] S. Li, Q. Yao, Y. Chi, J. Yan, and K. Cen, "Pilot-Scale Pyrolysis of Scrap Tires in a Continuous Rotary Kiln," Ind. Eng. Chem. Res., no. 1, pp. 5133-5145, 2004.

[21] M. Ambrosewicz-walacik and M. Walacik, "Production of fuel blends from diesel oil and waste products," vol. 171, no. 4, pp. 255 $258,2017$. 